\title{
Congress wakes up to climate change
}

\section{Colin Macilwain, Washington}

Advocates of action to tackle climate change won an influential ally last week, as Senator John McCain's (Republican, Arizona) Senate Commerce Committee heard leading scientists testify that humankind is causing significant global warming.

Other congressional hearings in recent years have pitched global warming 'sceptics' against the larger group of climate scientists who believe that greenhouse-gas emissions are contributing to climate change - creating the impression that researchers are in disarray. But McCain's hearing presented a more sober picture of the evidence.

Neal Lane, Bill Clinton's scientific adviser, said there was now "a significant consensus" on the issue. "Basically, the debate has changed from 'are we warming the Earth?' to 'how much are we warming the Earth?', Lane said.

Each of the five scientific witnesses called before the hearing repeated this perspective. These included John Christy, a climate scientist at the University of Alabama, who has sometimes been sceptical about the human component of climate change.

McCain, who recently failed to win the Republican nomination for this November's presidential election, said the hearing was a response to concerns encountered on the campaign trail.

"In town-hall meeting after town-hall

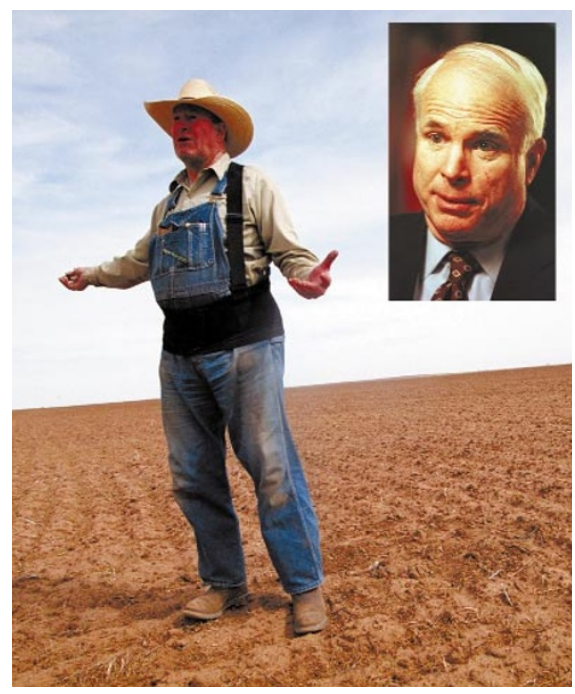

Warm words: in the wake of a US drought, John McCain (inset) speaks out on climate change.

meeting, young people would stand up and say: 'What is your position on global warming??" McCain said. "I don't have a plan, but I do believe that policy-makers should be concerned about mounting evidence of global warming."

Environmentalists greeted his approach as further evidence that the tide of US opinion is slowly turning in favour of action to limit greenhouse-gas emissions.

In the past year, major corporations including Ford, General Motors and DuPont have withdrawn their support from the Global Climate Coalition, which has campaigned against such action. Some of these corporations have also set their own internal targets for reducing emissions.

Until McCain's hearing on 17 May, Congress had not reflected this shift. It is trying to prevent the US government spending money on carbon-emission trading schemes or other components of the Kyoto Protocol. The Clinton administration, which signed the protocol, has not asked the Senate to ratify it, knowing it would refuse.

Drafts of the third assessment report of the Intergovernmental Panel on Climate Change, to be published next year, state that human activities are contributing to global warming.

The US government, meanwhile, is set to publish its own national assessment of the consequences of climate change next month. This is intended to influence the debate by showing Americans the relevance of the problem, but some industrial groups have already questioned its neutrality.

The next conference of the parties to the Kyoto Protocol will take place in The Hague in November, a week after a presidential election that will help to determine the United States' position. Whatever happens, advocates of the Kyoto Protocol do not envisage the US Senate ratifying it before 2003.

\section{French unions upset by plans for physiology centre}

\section{Heather McCabe, Paris}

France's biomedical research agency, INSERM, has clashed with some of its research staff over an ambitious proposal to build a new research centre outside Paris. Focusing on physiology and physiopathology, the centre would cost FF500 million (US\$69 million). It would have five animal facilities, holding almost 20,000 animals, and would be equipped with advanced imagery and computer systems.

The aim of the proposal is to collect the research activities of several institutions under one roof. It would bring together physiologists currently working for INSERM, the National Centre for Scientific Research (CNRS), the National Institute for Agronomic Research (INRA), and the lifesciences department of the French Atomic Energy Commission (CEA). Researchers from the Paris-Sud XI University in Orsay and the University of Paris XII in Créteil would also be involved.

INSERM officials say the centre would provide a boost to research in physiology, which has suffered over recent years compared with the more popular areas of the life sciences, such as molecular biology.

But while accepting the need to redress this balance, labour unions representing research staff argue that the money would be better spent on strengthening and upgrading existing research centres.

Plans for the project are awaiting the green light from the Ministry of Research. One author of the proposals, Marc Peschanski, head of an INSERM research unit on neuroplasticity and therapeutics in Paris, says he expects a response within the next few months.

The regional council of the Ile-de-France, which covers Paris, has already voiced its support for the proposal. According to Peschanski, the region has agreed in principle to finance half of the project over two years, although it will not provide any funds before 2002 .

The new centre also has the support of Claude Griscelli, the director-general of INSERM, who describes the project as "very interesting". But he adds: "We should not put everything in one institute. We need to put resources into existing facilities. One cannot be done without the other."

The National Union of Scientific Research Workers (SNTRS) - one of the unions representing scientific employees goes further. It says that, before creating a single large research centre, government research agencies should first build on existing physiology centres to form a modern network of facilities.

Union member Jean-Pierre Bazin of INSERM's laboratory on quantitative medical imagery in Paris says that the proposal for the 'physiopole' "lacks the sort of long-term scientific planning necessary for a project of this size". He believes that the scientific objectives have not been well identified.

Bazin points out that scientists working for the other institutions to be included in the centre have not yet been consulted. Peschanski admits that consultations have yet to take place, but says the project is only in the preliminary stage of planning. 